\section{"Biophilic" planning, a new approach in achieving liveable cities in Iranian new towns - Hashtgerd case study}

\section{Maryam Ebrahimpour, Hamid Majedi \& Hossein Zabihi}

http://dx.doi.org/10.18820/2415-0495/trp70i1.1

Peer reviewed and revised March 2017

\begin{abstract}
Urbanization development in Iran has caused increasing critical problems, with the result that there is a need to review urban planning in this country. This article aims to explore the impact of biophilic planning on liveability, with special focus on the role of nature as part of society. The study was done in Hashtgerd, an Iranian new town, where an environmental analysis showed that this town can be developed on the West, North and North-West, due to the natural potential of the area.

Based on the literature review and content analysis (selective coding), components of biophilic planning and liveability of new towns have been identified and used to test the opinions of 382 residents in Hashtgerd on biophilic planning and liveability of a new town in Iran. The data from the questionnaire were collected and processed, using SPSS software. The final dependent and independent variables were identified and analysed. Correlation coefficients in the regression analysis were used to analyse the effects on each other between the identified dependent and independent variables.

According to the results and findings, urban management (a component of biophilic planning) has the biggest effect in achieving liveable cities. The outcome of the study is crucial for construction and urban planning team members, clients and environmentalists. Another reason, that is particularly relevant to developing countries, is the natural potential and related industries to create beneficial social and economic impacts.
\end{abstract}

Keywords: Biophilic planning, liveability, new town, Iran

\section{“BIOPHILIC” BEPLANNING, 'N NUWE BENADERING IN DIE BEREIKING VAN BEWOONBARE STEDE IN NUWE DORPE VAN IRAN - HASHTGERD GEVALLESTUDIE}

Die ontwikkeling van verstedeliking in Iran het groeiende kritieke probleme veroorsaak en dit het nodig geword om 'n oorsig oor stadsbeplanning in hierdie land te kry. Die doel van hierdie artikel is om die impak van "biophilic" beplanning op leefbaarheid, met spesiale fokus op die rol van die natuur as deel van die samelewing, te verken. Die studie is gedoen in Hashtgerd, 'n Iraanse nuwe dorp omdat omgewingsanalises getoon het dat hierdie dorp in die Weste, Noorde en Noordweste ontwikkel kan word as gevolg van sy natuurlike vermoëns.

Gebaseer op die literatuurstudie en inhoudsontleding (selektiewe kodering) is komponente van "biophilic" beplanning en leefbaarheid van nuwe dorpe geïdentifiseer en gebruik om die opinies van 382 inwoners in Hasthgerd oor "biophilic" beplanning en leefbaarheid van ' $n$ nuwe dorp in Iran te toets. Nadat die data verkry uit die vraelyste versamel en verwerk is deur middel van SPSS sagteware, is die finale afhanklike en onafhanklike veranderlikes geïdentifiseer en ontleed. Korrelasiekoeffisiënte in die regressie-analise is gebruik om die uitwerking op mekaar tussen die geïdentifiseerde afhanklike en onafhanklike veranderlikes te ontleed.

Volgens die resultate en bevindinge, het stedelike bestuur (komponent van "biophilic" beplanning) die grootste effek om 'n bewoonbare stad te verwerklik. Die uitkoms van die studie is baie belangrik vir konstruksie- en stedelike beplanning spanlede, kliënte en omgewingsbewustes. Die waarde van die studie is veral van toepassing op ontwikkelende lande waar daar ' $n$ natuurlike potensiaal en verwante bedrywighede is om ' $n$ maatskaplike en ekonomiese impak te skep.

Sleutelwoorde: "Biophilic" beplanning, bewoonbaarheid, nuwe dorpe, Iran

\section{MORERO WA LERATO LA \\ BOPHELO "BIOPHILIC PLANNING" \\ KATAMELO E NTJHA BAKENG \\ SA HO FUMANA TOROPO YA \\ BODULO BO BOLOKEHILENG \\ DITOROPONG TSE NTJHA TSA \\ IRAN - THUTO YA MAHLALE YA \\ HASHTGERD}

Ntshetsopele ya toropo ka hare ho Iran e entse hore ho be le mathata a kotsi, a eketsehileng, ka ditlamorao tsa hore ho na le thokeho ya ho lekodisisa thophiso ya toropo naheng ena. Atikele ena e ikemiseditse ho lekola kgahlamelo ya morero wa lerato la bophelo "biophilic" hodima kgonahalo ya bodulo bo bolokehileng, ka tsepamiso ya maikutlo e ikgethileng hodima seabo sa thaho jwaloka karolo ya setjhaba. Patlisiso/ thuto ena e entswe Hashtgerd, toropo e ntjha ya Iran, moo tekolo ya tikoloho e bontshitseng hore toropo ena e ka kgona ho ntshetswapele ka Bophirima, ka Leboya, le ka Leboya-Bophirima, ka lebaka la bokgoni ba thaho ba sebaka seo.

Ho ya ka tekodisiso ya dingolwa le tekolo ya dintlha (khouding e qoollang), dikarolo tsa morero wa lerato la bophelo "biophilic" le kgonahalo ya ho phela ditoropong tse ntjha; di qoollotswe, mme disebedisitswe holekola maikutlo a baahi ba 382 Hashtgerd mabapi le morero wa lerato la bophelo "biophilic" le kgonahalo ya ho phela toropong e ntjha ka hare ho Iran. Dintlha tse bokelletsweng ho ya ka lenane la dipotso di ile tsa bokanngwa le ho tsamaiswa ho sebediswa dinolo "software" tsa SPSS. Diphetoho tsa ho qetela tse ikemetseng le tse sa ikemelelang di ile tsa qoollwa, le ho lekolwa. Dikarolo tse bapileng tekolong ya kgutlelo morao di ile tsa sebediswa ho lekola dikgahlamelo tse ding le tse ding tse mahareng a diphetoho tse qoollotsweng tse ikemetseng le tse sa ikemelang.

Ho ya ka diphetho le diphumano, taolo ya toropo (karolo ya morero wa lerato la bophelo "biophilic") e na le kgahlamelo e kgolo ka ho fetisisa ho fumaneng ditoropo moo ho kgonwang ho phela teng. Sephetho sa thuto se bohlokwa bakeng sa kaho le ho ditho tsa sehlopha sa tlhophiso ya toropo, ho bareki le ho ba tsa thuto ya tsa tikoloho. Lebaka le leng, le amanang haholo le dinaha tse holang, ke bokgoni ba thaho le diindasteri tse amehang, ho etsa dikgahlamelo tsa botho le tsa moruo tse nang le molemo.

The author declare no conflict of interest for this title or article.

Mss Maryam Ebrahimpour, PhD candidate, Faculty of Art and Architecture, Science and Research branch, Islamic Azad University, Tehran, Iran

Prof. Hamid Majedi, Professor, Faculty of Art and Architecture, Science and Research Branch, Islamic Azad University, Tehran, Iran

Prof. Hossein Zabihi, Associate Professor of Art and Architecture, Science and Research Branch, Islamic Azad University, Tehran, Iran 


\section{INTRODUCTION}

To transition from the sanitary city of the twentieth century to the sustainable city of the twentyfirst, new knowledge needs to be developed and applied in order to understand the role of nature in cities (Vitousek, Mooney, Lubchenco \& Mellilo, 1997: 494-499).

Because of the size and impact of cities, increasing attention has been paid to their potential to remediate some of their own environmental impacts and reduce distant resource imports, using ecosystem services such as tree canopy cover, and developing underutilized or undeveloped autochthonous resources such as water (Beatley, 2010; Platt, 1994; McPherson, Simpson, Peper, Maco \& Xiao, 2005: 411416; Pataki, Carreiro, Cherrier, Grulke, Jennings, Pincetl, Pouyat, Whitlow \& Zipperer, 2011: 27-36; Pincetl, Gillespie, Pataki, Saatchi \& Saphores, 2012: 475-493).

Interest in the remediating role of nature in the city has had a slow and steady history since the rise of the industrial city, including some of the early designs of Fredrick Law Olmsted, using water features in urban parks to remediate water pollution, and his advocacy of parks as 'lungs' to counter pollution.

Ebenezer Howard's Garden cities, Le Corbusier's Contemporary city, and Frank Lloyd Wright's Broad acre city plan also reflect ideas of the importance of urban nature; urban designers and ecologists such as Ian McHarg's (1971) Design with nature, and Spirn (1984), as well as planners such as Rutherford Platt (1994) and open-space advocates such as Charles Little (1992) took up the refrain in the second half of the $20^{\text {th }}$ century. These latter thinkers advocated that nature should be considered both in designing new urban development (watersheds and their functions, for example), and in positioning buildings in cities to enhance natural elements such as cooling winds in hot summers, or increasing the availability of sunlight in winter. In the 2000s, there was an explosion of interest in the distribution of parks and open spaces relative to the equitable provision of ecosystem services (Boone, Buckley, Grove \& Sister, 2009: 767-782; Heynen, Perkins \& Roy, 2006: 3-25; Wolch, Wilson \& Fehrenbach, 2005: 4-35; Pincetl, 2010: 43-58).

A 'biophilic city' is a green city, a city with abundant nature and natural systems that are visible and accessible to urbanites. It is not only about physical conditions and urban design (parks, green features, urban wildlife, and walkable environments), but also about the spirit of a place, its emotional commitment and concern about nature and other forms of life, its interest in, and curiosity about nature, which can be expressed in the budget priorities of a local government as well as in the lifestyles and life patterns of its citizens. On the other hand, a 'biophilic city' is at its heart a biodiversity city, a city with abundant nature, a place where, in the normal course of work, play and life, residents feel, see, and experience rich nature (plants, trees, and animals) (Beatley, 2010: 45).

Urbanization development in Iran and in the world has caused increasing critical problems, with the result that there is a need to review urban planning in this country. Spatial distribution of cities and population and their control and management were not included in a comprehensive national plan; the problems arising from rapid urban growth have become complex. It is necessary to pay attention to urban space quality, due to the influx of people. Biophilic planning and liveability issues are important in new towns. The four new towns of Andisheh, Pardis, Parand, and Hashtgerd are located and built near the capital of Iran (Tehran). For this study, Hashtgerd was selected, due to possible future development and environmental potential. Both the Daghestan fault line and the Northern-Alborz fault line near the town are considered a natural risk, as soil movement is likely to occur when the faults become active. Natural and environmental analyses of the new towns indicate that Hashtgerd can be developed in the West,
North and the North-West due to its natural potential.

This article aims to explore the impact of biophilic planning on liveability, with special focus on the role of nature as part of society. The following research questions were examined:

- Is it possible to achieve liveable cities by focusing on biophilic planning?

- What are biophilic factors?

- What factor is the most effective on liveability?

\section{DEVELOPMENT OF PLANNING UP TO BIOPHILIC PLANNING}

\subsection{Biophilia and biophilic concepts}

Biophilia, a term that originates from Greek, means 'love of life' (Callicott, n.d.: online). It was coined by the social psychologist Erich Fromm and populated in the 1980s, as Edward O. Wilson pioneered a new school of thought focused on this concept, which he defined as "the urge to affiliate with other forms of life". Wilson's Biophilia Hypothesis asserts that people need to have contact with nature and with the complex geometry of natural forms, just as they require nutrients and air for metabolism (Kellert, 2005).

In 1995, William Rees, co-author of Our ecological footprint: Reducing human impact on the earth (1996), and Boone \& Modarres (2007: 296) as well as other authors suggested that the greatest opportunities to make the changes necessary for general sustainability can be found in cities. Planners such as Scott Campbell (1996: 296) included environmental thinking as part of sustainable thinking for cities, including bioregionalism as a guiding principle, as did Timothy Beatley and Kristy Manning (1997), among others.

That we need daily contact with nature in order to be healthy, productive individuals, and indeed we have coevolved with nature, is a critical insight of Harvard myrmecologist and conservationist E. O. Wilson. Wilson popularized the 
term "biophilia" two decades ago to describe the extent to which human beings are determined to connect with nature and other forms of life. More specifically, Wilson describes it as follows: "Biophilia ... is the innately emotional affiliation of human beings to other living organisms. Innate means hereditary and hence part of ultimate human nature" (Wilson, 1993: 31; Gruchow, 1995). To Wilson, biophilia is a "complex of learning rules" developed over thousands of years of evolution and human-environment interaction: "For more than 99 percent of human history people have lived in huntergatherer bands totally and intimately involved with other organisms."

During this period of history, and further back in history, human beings depended on an exact learned knowledge of crucial aspects of natural history. In short, the brain evolved in a bio-centric world, not a machine-regulated world. It would, therefore, be quite extraordinary to find that all learning rules related to that world have been erased in a few thousand years, even in the tiny minority of peoples who have existed for more than one or two generations in wholly urban environments (Wilson, 1993: 32).

The importance of urban green spaces and urban forests is increasing worldwide, due to the expansion of urban land fuelled by urbanization. The provision of parks and green spaces in urban areas makes a vital contribution to the quality of urban life. Nature is beneficial for human beings in various ways; people in cities do not get the opportunity to have intimate contact with nature. Realizing the importance of nature in human life, theorists and researchers associated with biophilia argue that we need to re-imagine cities as 'biophilic cities' (Beatley, 2010). "A Biophilic city is a city abundant with nature, a city that looks for opportunities to repair and restore and creatively insert nature wherever it can" (Beatley, 2010: 2).

The successful application of biophilic design necessitates consistently adhering to certain basic principles. These principles represent fundamental conditions for the effective practice of biophilic design. They include:

1. Biophilic design requires repeated and sustained engagement with nature.

2. Biophilic design focuses on human adaptations to the natural world that, over evolutionary time, have advanced people's health, fitness and wellbeing.

3. Biophilic design encourages an emotional attachment to particular settings and places.

4. Biophilic design promotes positive interactions between people and nature that encourage an expanded sense of relationship and responsibility for the human and natural communities.

5. Biophilic design encourages mutual reinforcing, interconnected, and integrated architectural solutions (Kellert, 2012).

Biophilic design further seeks to sustain the productivity, functioning and resilience of natural systems over time. Alterations of natural systems inevitably occur as a result of major building construction and development. Moreover, all biological organisms transform the natural environment in the process of inhabiting it. Based on studied related theories, Figure 1 illustrates biophilic planning features.

\subsection{Liveable concept}

In the Oxford Advanced Learner Dictionary, Hornby \& Turnbull (2010) refer to liveability as being "fit for life". It can be said that, in 1981, Donald Appleyard introduced the first concept of liveability as liveable streets (Appleyard, 1981). Jacobs and Appleyard (1987: 115-116) defined liveability as a city where every individual can live relatively easily; this is the necessary goal of a proper urban environment.

Liveable city refers to an urban system that helps the psychological, social, physical and personal wellbeing of all residents (Cities PLUS, 2003) who have the same opportunity to participate in, and benefit from the economic and political life of the city. Liveability means that we experience ourselves as citizens in the city (Castellati, 1997: 19-33).

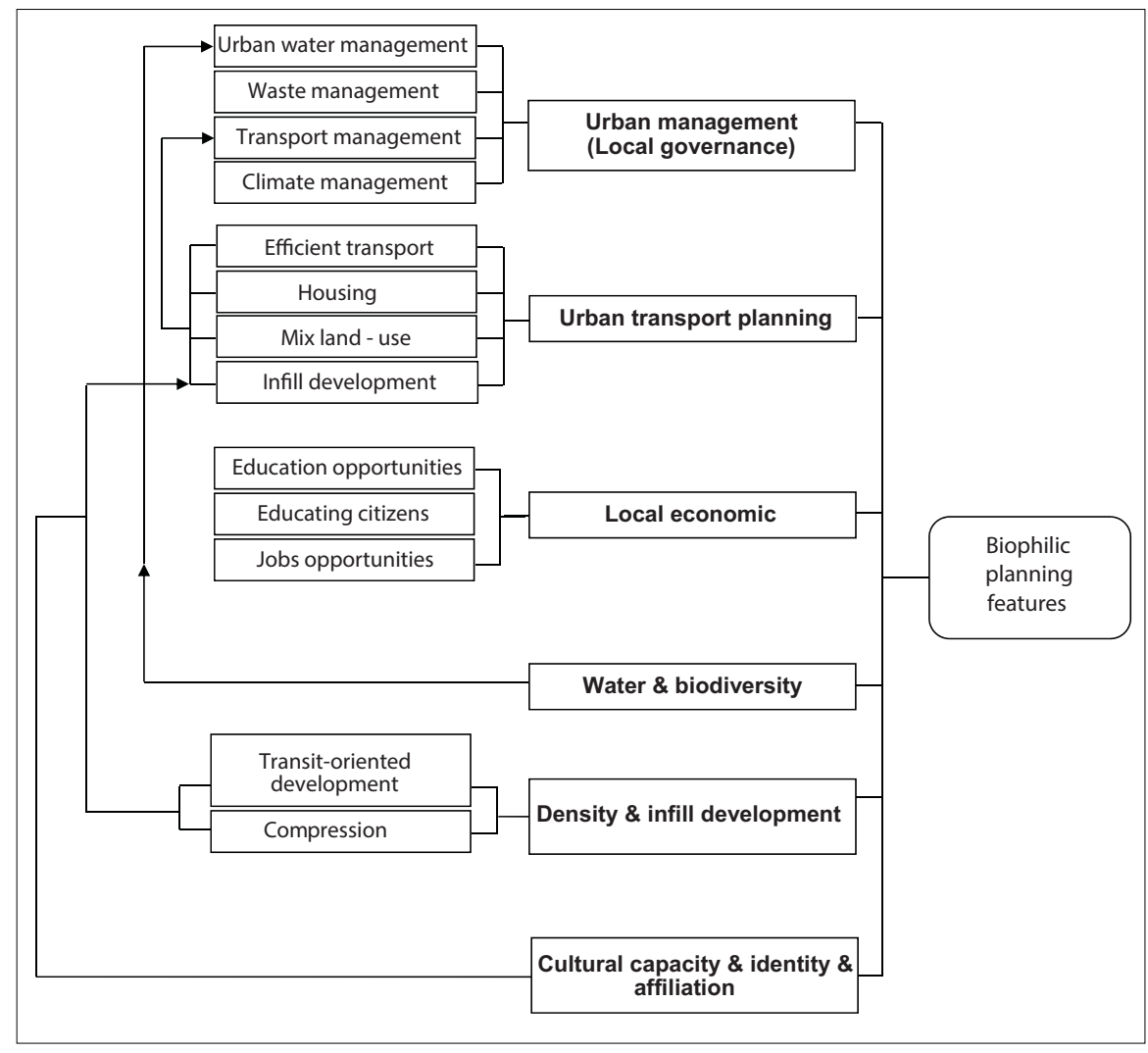

Figure 1: Biophilic features

Source: Researchers 


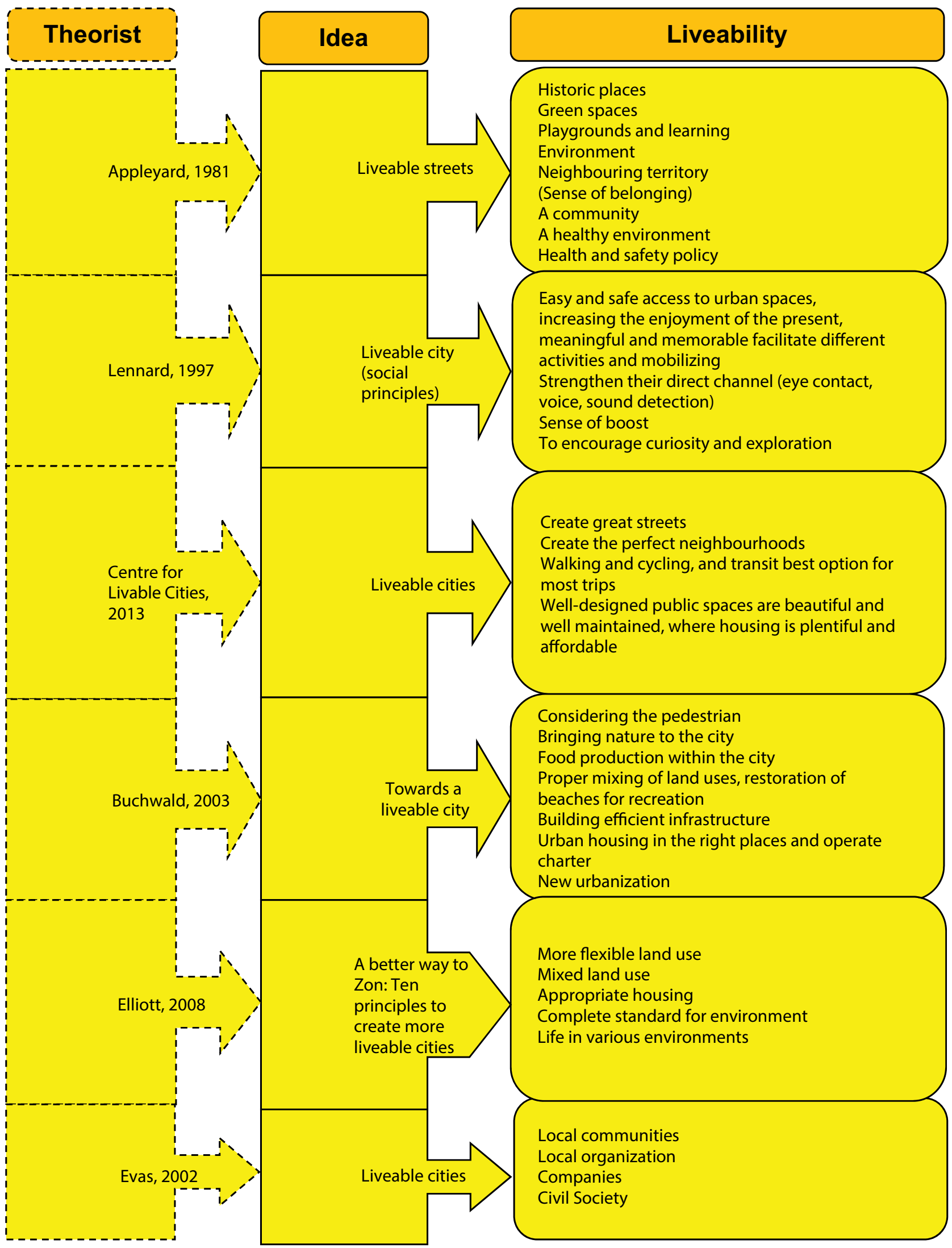

Figure 2: Different ideas about liveability

Source: Researchers 
Liveable city is a city where we can live a healthy life. It is an attractive, valuable, safe city for children and seniors (Hahlweg, 1997: 13-19).

These cities pay attention to creating architecture, street views and public spaces that facilitate the presence of city inhabitants in public areas. These cities are committed to reducing traffic and solving the safety problems of pollution and noise, using a range of mechanisms (Crowhurst \& Lennard, 1987).

In 1997, Henry Lenard defined some factors for the bases of the city. He defined liveable city as a living organism. However, the metaphor of the city as an organism can act as a powerful conceptual framework. This framework allows us to simultaneously test different components and focus on the interdependence of these components and the natural environment (Timmer \& Seymoar, 2005). Mercer Institute (2014) defined the index of living quality as political and social environment, cultural and social environment, economic environment, fun, products, habitats, clinical consideration, schools and teaching, public services, and transportation (Mercer Institute, 2014).

The Economist Intelligence Unit defined the variables of life quality as income, health, political and security stability, family life, social life,

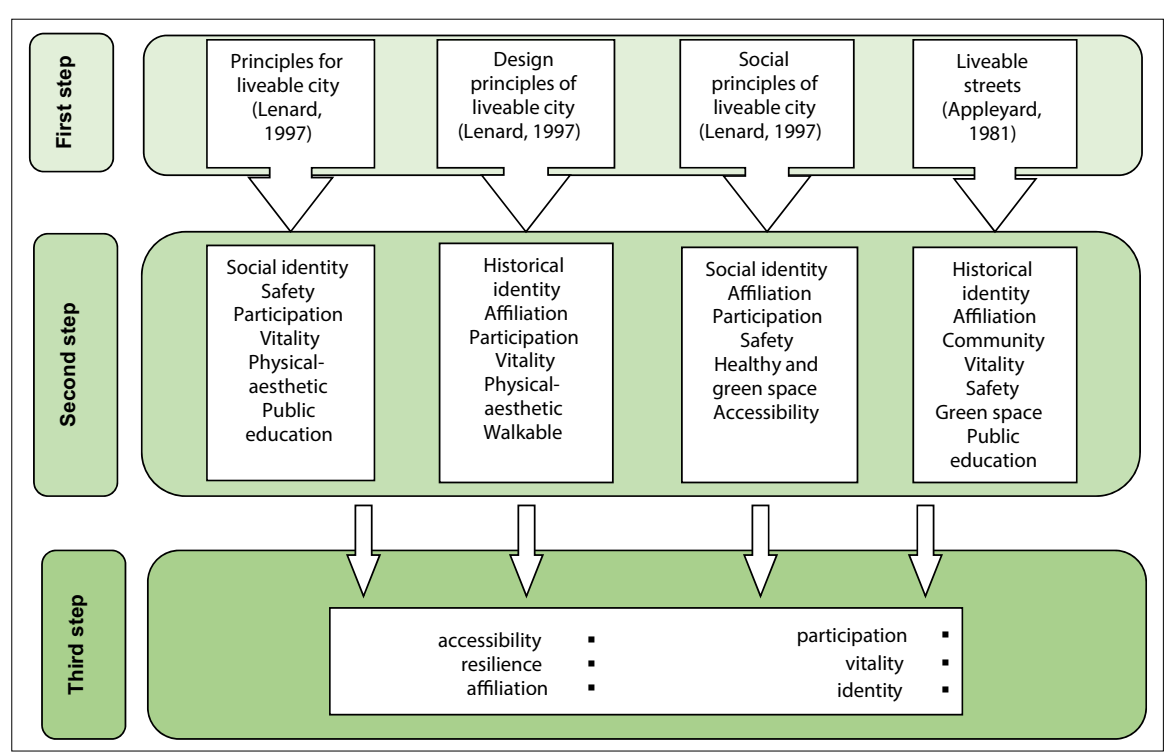

Figure 3a: Concluded liveable components

\section{Source: Researchers}

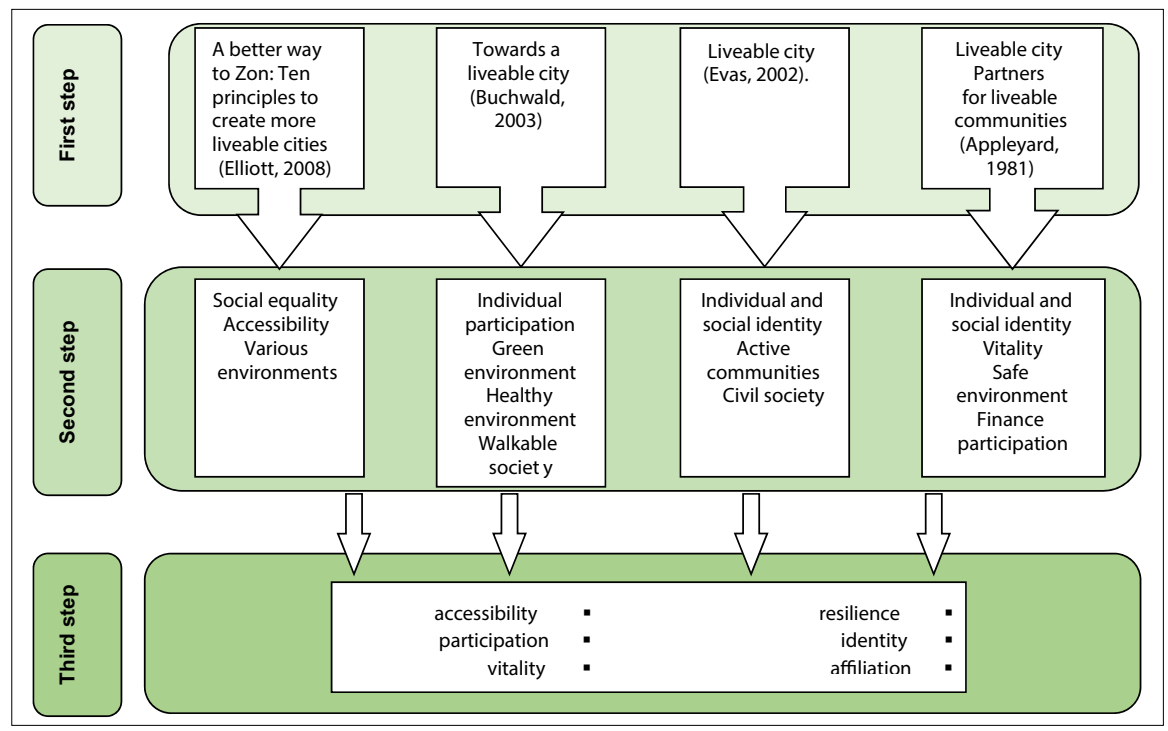

Figure 3b: Concluded liveable components

Source: Researchers climate and geography, job security, political freedom, and sexual equality (Economist Intelligence Unit, 2013). Since 2008, the economist journal published its report about liveability index in the world's big cities. The aim of these series of reports, which are analysed by experts and city services, is to obtain the statistics of liveability quality or capability of life based on standards of great cities. Figure 2 shows various theories about liveability; Figures $3 a$ and $3 \mathrm{~b}$ show a summary of liveable components reviewed

\section{IRANIAN NEW TOWN SOLUTION TO POPULATION GROWTH AND URBANIZATION}

Prior to 1921, Iran enjoyed a reasonable system of urbanization and urban development. It continued to be a homogenous one until 1956 when no city was superior to the other. Since the late 1950s, with rural population invading the cities and increasing urban population, the country's current problems gradually emerged. One of the most evident instances of immigration in Iran is physical and spatial instances, in the form of settlement in slums, which will eventually accelerate urbanization and the physical growth of big cities, particularly metropolises (Ajza Shokouhi \& Ghrakhlou \& Khazaee, 2012: 11).

The rapid growth of urban population and the patterns of urban population distribution require government plans to settle the future urban population in the existing urban areas and new towns. Therefore, since 1981, the government has started establishing new towns, with the aim of absorbing population overflow, reducing economic load of metropolises, preventing big cities to extend irregularly, local extension, optimal population distribution, and so on. In this regard, 32 cities were located and 17 towns were built. The four towns of Andisheh, Pardis, Parand, and Hashtgerd were located and built near Tehran, the largest metropolis in Iran (Ajza Shokouhi, Ghrakhlou \& Khazaee, 2012: 11). 
Building new towns, as a basic solution to the country's urbanization system began in 1981 and is still continuing. After more than three decades of this activity, it seems necessary to investigate the reasons why population growth is higher in some towns. Hashtgerd town was chosen for this study, as it is the most populated new town near Tehran.

\section{RESEARCH METHODOLOGY}

\subsection{Case study of Hashtgerd}

One of the main new towns in Iran is Hashtgerd. This city, located 80 kilometres west of Tehran and 25 kilometres east of Karaj, was planned as an overspill city for the fast-emerging megacities of Tehran and Karaj. It was approved by the high council of architecture and urban planning of Iran in 1993 (FMER, n.d.: 2).

Hashtgerd is the most populated of the new towns located in the Tehran metropolitan area (Zebardast \& Jahan Shah Lou, 2007: 5-22; Pakzad, Hosseinzadeh Lotfi \& Jahan Shah Lou, 2007: 591-600). At the end of its projected 25-year construction period, this new town was designed to accommodate a population of 500,000 (Ziari \& Gharakhanlou, 2009: 143-154). According to the latest official national census (2006), Hashtgerd has a population of 45,332 (Wikipedia, 2017: online).

Hashtgerd was found to be suitable for this study, as it typifies the majority of Iranian new towns (Zebardast \& Jahan Shah Lou, 2007: 5-22). In addition, compared with other new towns, Hashtgerd's areas under construction are significant and the town's inhabitants have a high rate of obesity and hypertension (Bahrami, Sadatsafavi, Pourshams, Kamangar, Nouraei, Semnani, Brennan, Boffetta \& Malekzadeh, 2006). On the other hand, another reason for choosing Hashtgerd new town is its natural facilities that connect the city with the surrounding environment and healthy activities (biophilic principle). Figure 4 shows Hashtgerd's geographical situation as a new town.

Hashtgerd new town, like many other new towns in Iran and elsewhere in the world, grapples with immediate, significant, technical or economic challenges. It is a fledgling community seeking its own identity.

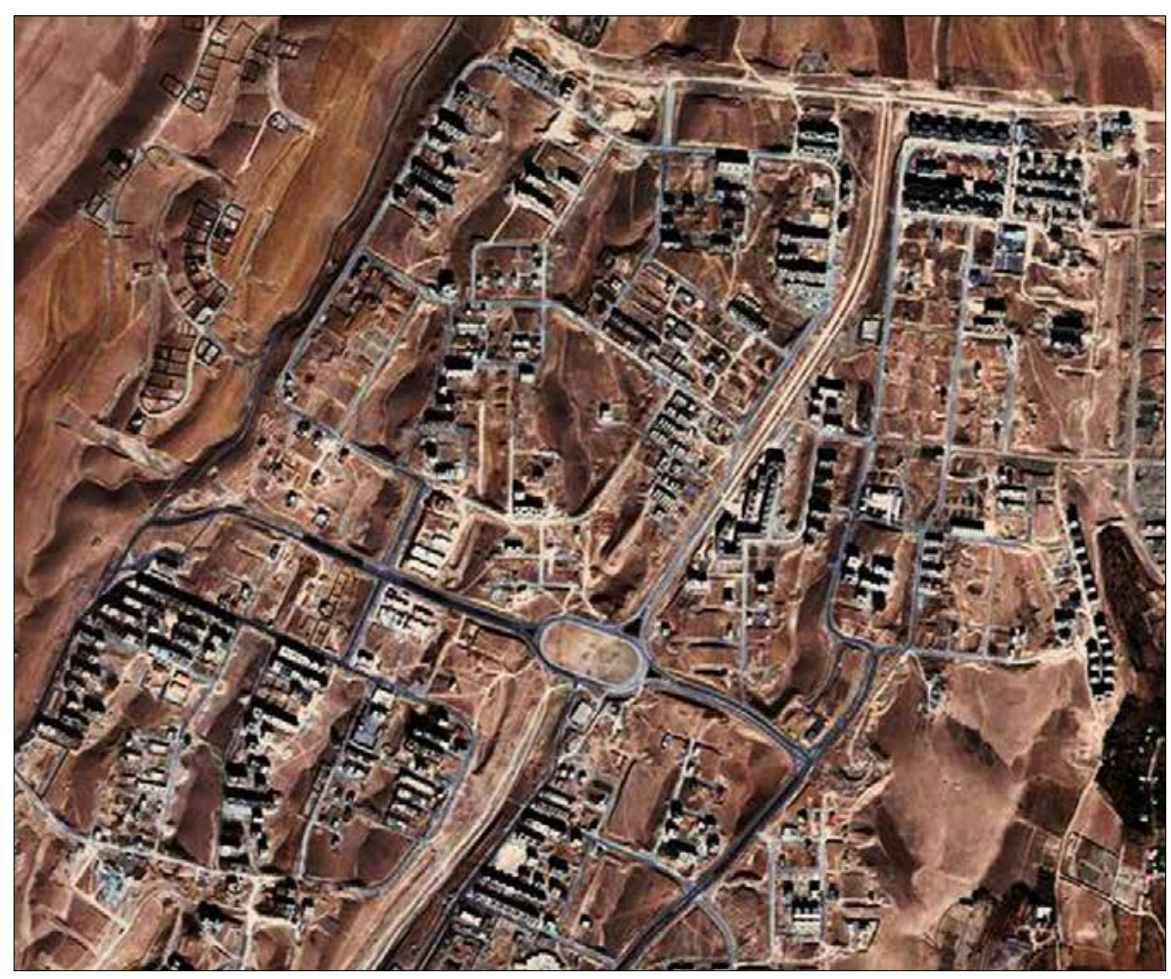

Figure 4: Physical-spatial characteristics of Hashtgerd new town.

Source: http://maps.google.com/maps?hl=en\&tab=wl.
The local and national levels are not integrated in all respects; this often leads to suboptimal realisations, a low or inefficient use of local talents and human resources, and a lack of identification with the new environment by the inhabitants, the businesses and the representatives of civil society.

\subsection{Research methods}

This article explores the impact of biophilic planning on liveability, with special focus on the role of nature as part of society. An extensive literature review on biophilic planning and liveability was done to identify biophilic and liveability planning components (Mayring, 2000: online). Subsequently, a case study of a city that applies biophilic and liveability planning components was generated. The example city - Hashtgerd - was selected from the literature based on various natural and environmental elements, typifying the majority of Iranian new towns (Zebardast \& Jahan Shah Lou, 2007: 5-22).

\subsubsection{Data collection}

The use of qualitative content analysis data reduction (selective coding) allowed the researcher to develop dominant themes and common data (Thomas, 2006: 240), in order to create a proposed model based on the literature reviewed. In the case study, semi-structured interviews with 382 Hashtgerd new town residents involved a series of forty questions that were used to obtain the opinions from residents regarding the effect of biophilic planning on liveability in Hashtgerd new town. Questions 1-3 asked biographic information. All other questions testing the components associated with liveable cities were set up based on a fivepoint Likert scale (where 1=very good, 2=good, 3=moderate, 4=poor, and $5=$ very poor). Likert-type or frequency scales use fixed choice response formats and are designed to measure attitudes or opinions (Bowling, 1997; Burns \& Grove, 1997). These ordinal scales measure levels of agreement/ disagreement. The issues of validity and reliability were confirmed based on Cronbach's alpha, with an average reliability level of 0.862 . 


\subsubsection{Sample size}

In Hashtgerd new town, with a population of over 45,332 people, a sample size of 382 households was selected from the residential units. Questionnaires were completed and the required data were obtained. The Krejcie \& Morgan table for sample size formulas indicates that, for a population equal to or over 40,000 , a sample size of 380 is valid (Krejcie \& Morgan, 1970).

\subsubsection{Data analysis and interpre- tation of findings}

Based on the literature review and content analysis (selective coding), components of biophilic planning and liveability of new towns have been identified and used to propose a concept model of biophilic planning and liveability of a new town in Iran. Having collected and processed the data from the questionnaire using SPSS software, the final dependent and independent variables were identified and analysed. Correlation coefficients in the regression analysis were used to analyse the effects on each other between the identified dependent and independent variables (Uyanik \& Güler, 2013: 234). In this article, liveability components were taken as independent variables and the biophilic planning components were considered the dependent variables.

\section{FINDINGS}

\subsection{Questionnaire results}

Based on a five-point Likert scale, where 1=very good, 2=good, 3=moderate, 4=poor and 5=very poor, Table 1 shows the average mean scores from responding residents of Hashtgerd in terms of vitality, sense of place, identity, access, participation and resilience, as the six proposed components associated with liveable cities.

Questions (Q10-Q16) on access criteria were rated the highest, with an average mean score of 2.9705 ; the component participation was rated the lowest, with a total average of 2.3691. Vitality was rated, based on questions 4 and 5 (Q4, Q5), with an average of 2.7251 .

Table 1: $\quad$ Mean value of the components associated with liveable cities

\begin{tabular}{|l|c|c|}
\hline \multicolumn{1}{|c|}{ Variable } & Average mean score (N=382) & Rank \\
\hline Access & 2.9705 & 1 \\
\hline Affiliation & 2.9031 & 2 \\
\hline Vitality & 2.7251 & 3 \\
\hline Identity & 2.6257 & 4 \\
\hline Resilience & 2.4372 & 5 \\
\hline Participation & 2.3691 & 6 \\
\hline Average mean score for liveable cities & $\mathbf{2 . 6 7 1 8}$ & \\
\hline
\end{tabular}

Table 2: Average rating of components associated with biophilic planning

\begin{tabular}{|l|c|c|}
\hline \multicolumn{1}{|c|}{ Variable } & Average mean score (N=382) & Rank \\
\hline Environment & 3.4110 & 1 \\
\hline Biophilic housing & 3.2335 & 2 \\
\hline Urban management & 3.1440 & 3 \\
\hline Biophilic activities & 3.0694 & 4 \\
\hline Historical pattern & 3.0157 & 5 \\
\hline Infill development & 2.7866 & 6 \\
\hline Education & 2.7382 & 7 \\
\hline Average mean score for biophilic planning & $\mathbf{2 . 6 7 1 8}$ & \\
\hline
\end{tabular}

Q6 on affiliation scored an average of 2.9031 and Q7 on identity scored 2.6257. Q8 on resilience scored 2.4372 and $Q 9$ on participation scored 2.3691.

The average liveability score of 2.6718 is slightly less than the median of three, thus indicating that the average liveability is good.

Based on a five-point Likert scale, Table 2 shows the average mean scores from residents in Hashtgerd in terms of environment, biophilic activities, education, historical pattern, urban management, infill development, and biophilic housing, as the proposed components associated with biophilic planning in new towns.

Questions 17 and 18 on

"biophilic activities" show an average score of 3.0694. Other criteria such as Awareness and Education in questions 19 and 20 were investigated and show an average score of 2.7382. Standard Environment issues in questions 21-24 were reviewed and show an average score of 3.4110 . Biophilic housing in questions 36-40 was investigated and was rated an average of 3.2335. Questions 26 and 27 asked standard Urban management information and score an average of 3.1440 . Infill development, in questions 33 to 35, scored an average of 2.7866 . According to Table 2, Environment scored the highest average with
3.4110. Education was rated the lowest, with an average score of 2.7382. Overall, the average score for biophilic planning was 3.0567, which is equal to the median of 3 .

\subsection{Proposed liveable city concept model and variables}

Results from the questionnaire show that both the natural context (environment) and the planning context are important in the development of liveable cities.

Figure 5 shows the proposed concept model with the components that are important for a liveable city, based on the physical organisation as well as the social and economical organisation of a new city.

The model outlines the value components that are deemed significant in both the natural context and the planning context that lead to liveable cities through biophilic planning. In the natural context, the model proposes resilience, vitality, affiliation, identity, accessibility and participation as components for liveable cities, which are viewed as the independent variables. In the planning context, the model proposes biophilic activities, environment, historical pattern, infill development, urban management, biophilic housing and education as components for biophilic planning, which are considered the dependent variables. 


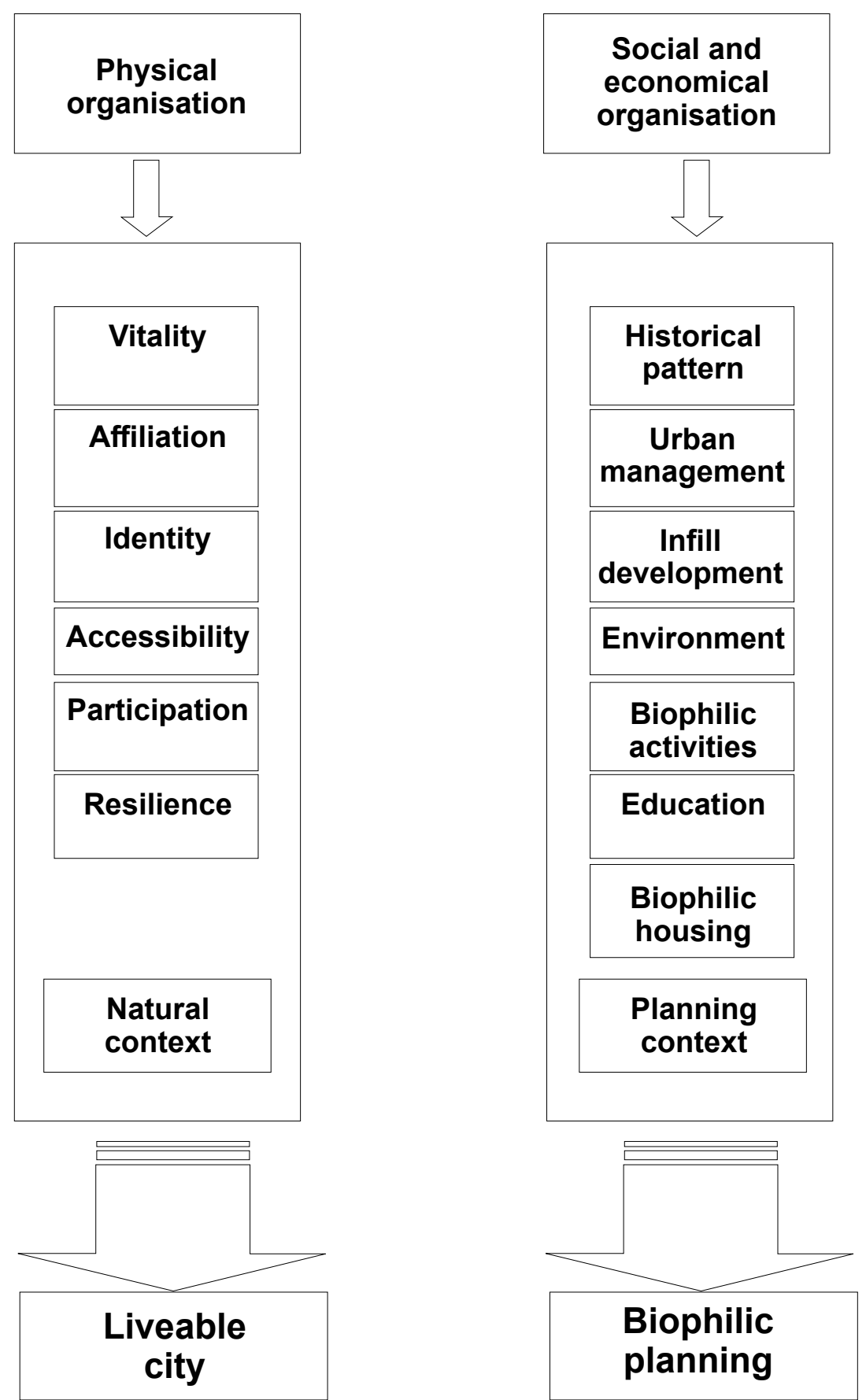

Figure 5: Liveable city concept model

Source: Researchers

Table 3: Ranking of biophilic planning variables in Vitality

\begin{tabular}{|c|l|c|c|}
\hline Ranking & \multicolumn{1}{|c|}{ Variable } & Sym in equation & B coefficient \\
\hline 1 & Biophilic activities & $\mathrm{B}$ & .247 \\
\hline 2 & Education & $\mathrm{E}$ & .211 \\
\hline 3 & Urban management & $\mathrm{U}$ & .209 \\
\hline 4 & Environment & $\mathrm{N}$ & .147 \\
\hline 5 & Biophilic housing & $\mathrm{H}$ & .058 \\
\hline 6 & Historical pattern & $\mathrm{P}$ & - \\
\hline 7 & Infill development & $\mathrm{I}$ & - \\
\hline
\end{tabular}


Table 4 shows the effects of biophilic planning components on the Identity component of liveability.

Regression equation 2 shows that Education change .296 units for every unit change in Identity. This means that, for every increase of one unit in Education, a $29.6 \%$ change in the Identity variable will occur in a positive direction. Education seems to have the highest effect on Identity.

In changes of one unit, the effects of other variables are listed below:

Urban management $(U)$ showed an increase and has a $4.4 \%$ effect on Identity.

Biophilic housing $(\mathrm{H})$ showed an increase and has a $28 \%$ effect on Identity.

Historical pattern $(P)$ showed an increase and has a $1.8 \%$ effect on Identity.

Biophilic activities, the Environment and Infill development had no significant effect on Identity. These factors were thus excluded from the regression equation.

Table 4: Ranking of biophilic planning variables in Identity

\begin{tabular}{|c|l|c|c|}
\hline Ranking & \multicolumn{1}{|c|}{ Variable } & Sym in equation & B coefficient \\
\hline 1 & Education & $\mathrm{E}$ & .296 \\
\hline 2 & Biophilic housing & $\mathrm{H}$ & .280 \\
\hline 3 & Urban management & $\mathrm{U}$ & .044 \\
\hline 4 & Historical pattern & $\mathrm{P}$ & .018 \\
\hline 5 & Biophilic activities & $\mathrm{B}$ & - \\
\hline 6 & Environment & $\mathrm{N}$ & - \\
\hline 7 & Infill development & $\mathrm{I}$ & - \\
\hline
\end{tabular}

Table 5: Ranking of biophilic planning variables in Affiliation

\begin{tabular}{|c|l|c|c|}
\hline Ranking & \multicolumn{1}{|c|}{ Variable } & Sym in equation & B coefficient \\
\hline 1 & Environment & $\mathrm{N}$ & .360 \\
\hline 2 & Historical pattern & $\mathrm{P}$ & .310 \\
\hline 3 & Urban management & $\mathrm{U}$ & .275 \\
\hline 4 & Infill development & $\mathrm{I}$ & .259 \\
\hline 5 & Biophilic activities & $\mathrm{E}$ & .172 \\
\hline 6 & Education & $\mathrm{H}$ & .078 \\
\hline 7 & Biophilic housing & & - \\
\hline
\end{tabular}

Table 6: Ranking of biophilic planning variables in Resilience

\begin{tabular}{|c|l|c|c|}
\hline Ranking & \multicolumn{1}{|c|}{ Variable } & Sym in equation & B coefficients \\
\hline 1 & Urban management & $\mathrm{U}$ & .836 \\
\hline 2 & Environment & $\mathrm{N}$ & .239 \\
\hline 3 & Infill development & $\mathrm{I}$ & .231 \\
\hline 4 & Biophilic activities & $\mathrm{E}$ & .222 \\
\hline 5 & Education & $\mathrm{H}$ & - \\
\hline 6 & Biophilic housing & $\mathrm{P}$ & - \\
\hline 7 & Historical pattern & & - \\
\hline
\end{tabular}

Historical pattern $(P)$ showed an increase and has a $31 \%$ effect on Affiliation.

Biophilic activities (B) showed an increase and has a $17.2 \%$ effect on Affiliation.

Education (E) showed an increase and has a $7.8 \%$ effect on Affiliation.

Biophilic housing has no effect on Affiliation. This factor was thus excluded from the regression equation.

\subsubsection{Resilience}

Equation 4 between Resilience and Biophilic planning variables was calculated as follows:

Equation 4: $\mathrm{Y}($ Resilience $)=$ $0.222 \mathrm{~B}+0.239 \mathrm{~N}+0.836 \mathrm{U}+0.231 \mathrm{I}$

Table 6 shows the effects of biophilic planning components on the Resilience component of liveability.

Regression equation 4 shows that Urban management change .836 units for every unit change in Resilience. This means that, for every increase of one unit in Urban management, a $83.6 \%$ positive increase in the Resilience variable will occur. It seems that Urban management has the biggest effect on Resilience.

In unit measurements of one, the effects of other variables are listed below:

Environment $(\mathrm{N})$ showed an increase and has a $23.9 \%$ effect on Resilience.

Infill development (I) showed an increase and has a $23.1 \%$ effect on Resilience.

Biophilic activities (B) showed an increase and has a $22.2 \%$ effect on Resilience.

Education, Biophilic housing and Historical pattern had no effect on Resilience. These factors were thus excluded from the regression equation.

\subsubsection{Partnership}

Equation 5 between Partnership and biophilic planning variables was calculated as follows: 
Equation 5: $\mathrm{Y}$ (Partnership) $=$ $0.126 \mathrm{E}+0.373 \mathrm{~N}+0.317 \mathrm{U}+0.093 \mathrm{~B}$

Table 7 shows the effects of biophilic planning components on the Partnership component of liveability.

Regression equation 5 shows that Environment changes .373 units for every unit change in Partnership. This means that, for every increase of one unit in Environment, a 37.3\% increase in the Partnership variable will occur in a positive direction. It seems that Environment has the biggest effect on Partnership.

In unit measurements of one, the effects of other variables are listed below:

Urban management (U) showed an increase and has a $31.7 \%$ effect on Partnership.

Education (E) showed an increase and has a $12.6 \%$ effect on Partnership.

Biophilic activities (B) showed an increase and has a $9.3 \%$ effect on Partnership.

Table 7: Ranking of biophilic planning variables in Partnership

\begin{tabular}{|c|l|c|c|}
\hline Ranking & \multicolumn{1}{|c|}{ Variable } & Sym in equation & B coefficients \\
\hline 1 & Urban management & $\mathrm{U}$ & .836 \\
\hline 2 & Environment & $\mathrm{N}$ & .239 \\
\hline 3 & Infill development & $\mathrm{I}$ & .231 \\
\hline 4 & Biophilic activities & $\mathrm{B}$ & .222 \\
\hline 5 & Education & $\mathrm{E}$ & - \\
\hline 6 & Biophilic housing & $\mathrm{H}$ & - \\
\hline 7 & Historical pattern & $\mathrm{P}$ & - \\
\hline
\end{tabular}

Table 8: Ranking of biophilic planning variables in Accessibility

\begin{tabular}{|c|l|c|c|}
\hline Ranking & \multicolumn{1}{|c|}{ Variable } & Sym in equation & B Coefficients \\
\hline 1 & Infill development & $\mathrm{I}$ & .554 \\
\hline 2 & Urban management & $\mathrm{U}$ & .228 \\
\hline 3 & Environment & $\mathrm{N}$ & .207 \\
\hline 4 & Biophilic activities & $\mathrm{H}$ & .145 \\
\hline 5 & Biophilic housing & $\mathrm{E}$ & .130 \\
\hline 6 & Education & $\mathrm{P}$ & \\
\hline 7 & Historical pattern & & \\
\hline
\end{tabular}

Table 9: Final equation: Liveability variables and biophilic planning

\begin{tabular}{|c|l|c|c|}
\hline Ranking & \multicolumn{1}{|c|}{ Variable } & Sym in equation & B coefficient \\
\hline 1 & Urban management & $\mathrm{U}$ & .192 \\
\hline 2 & Biophilic activities & $\mathrm{B}$ & .179 \\
\hline 3 & Environment & $\mathrm{N}$ & .171 \\
\hline 4 & Biophilic housing & $\mathrm{H}$ & .113 \\
\hline 5 & Education & $\mathrm{E}$ & .038 \\
\hline 6 & Historical pattern & $\mathrm{P}$ & .022 \\
\hline 7 & Infill development & $\mathrm{I}$ & .016 \\
\hline
\end{tabular}

Urban management (U) showed an increase and has a $22.8 \%$ effect on Accessibility.

Environment $(\mathrm{N})$ showed an increase and has a $18.7 \%$ effect on Accessibility.

Biophilic activities (B) showed an increase and has a $14.5 \%$ effect on Accessibility.

Biophilic housing $(\mathrm{H})$ showed an increase and has a $13 \%$ effect on Accessibility.

Resilience, Education and Historical pattern had no effect on Accessibility. These factors were thus excluded from the regression equation.

\subsection{Relations between liveability and biophilic planning}

Figure 6 visually presents the relations between the liveability variables (independent) and the biophilic planning variables (dependent).

The final equation between Liveability variables and biophilic planning was calculated as follows:

Equation 7: (Liveability) $=0.179 \mathrm{~B}+$ $0.038 \mathrm{E}+0.171 \mathrm{~N}+0.192 \mathrm{U}+0.016 \mathrm{I}+0.11$ $3 \mathrm{H}+0.022 \mathrm{P}$

The final equation shows the relation between biophilic planning variables and liveability of Hashtgerd new town. According to these equations, for every increase of one unit of Urban management, a $19.2 \%$ increase in liveability will occur in Hashtgerd. It seems that Urban management has the most impact on the liveability of new cities.

In unit measurements of one, the effects of each biophilic component on liveability are listed below:

Urban management (U) showed an increase and has a $19.2 \%$ effect on Liveability.

Biophilic activities (B) showed an increase and has a $17.9 \%$ effect on Liveability.

Environment $(\mathrm{N})$ showed an increase and has a $17 \%$ effect on Liveability.

Biophilic housing $(\mathrm{H})$ showed an increase and has a $11.3 \%$ effect on Liveability. 


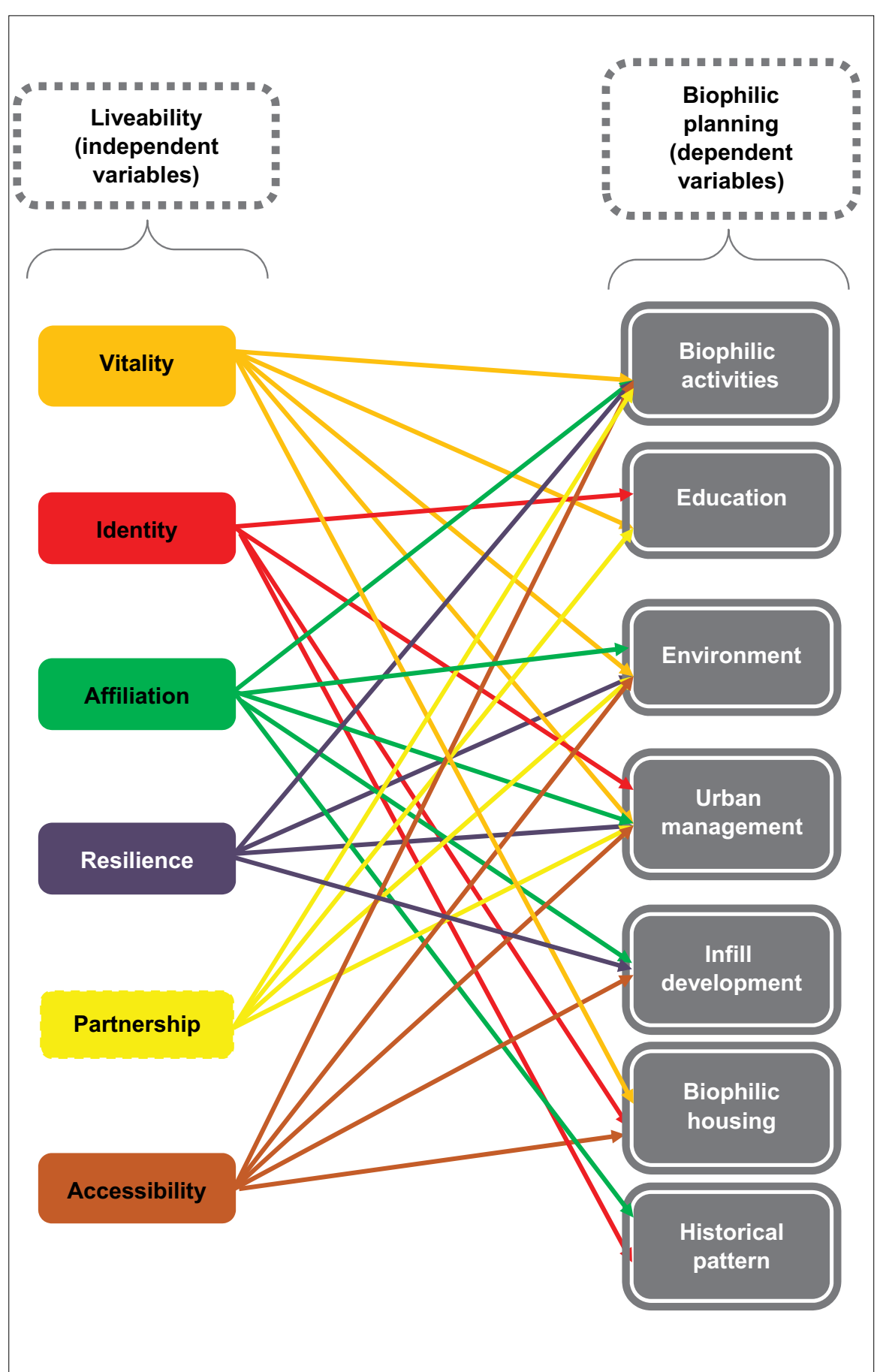

Figure 6: The relations between the variables

Source: Researchers

Education (E) showed an increase and has a $3.8 \%$ effect on Liveability.

Historical pattern $(P)$ showed an increase and has a $2.2 \%$ effect on Liveability.

Infill development (I) showed an increase and has a $1.6 \%$ effect on Liveability.

The regression equation confirms that biophilic planning achieves liveability in Hashtgerd new town.

\section{DISCUSSION}

The research focused on the achievement of liveable cities through a new planning approach, namely biophilic planning. Analysis of the literature and the results from the questionnaire survey reflected factors influencing biophilic planning in Hashtgerd new town.

The average liveability score of 2.6718 was slightly less than the median of three, indicating that the respondents rated the average liveability criteria in Hashtgerd as good. Overall, the average score for biophilic planning was 3.0567 , which is equal to the median of 3 , indicating that respondents rated the average biophilic planning components in Hashtgerd as good.

Biophilic planning appears to have potential as a way of providing an indication of the sustainability impacts of urban environment. In particular, it is innovative, as it provides a way to connect with nature. The residents rated access to nature (as liveable component) and environment (as biophilic planning component) the highest, as this will make individuals, families and communities healthier and happier and help forge new social connections and friendships that should make such cities more resilient.

According to the regression analysis findings (B coefficients), Urban management has the most impact on the liveability of new cities. Therefore, urban planners need to propose local strategies in Hashtgerd new town.

Biophilic activities has the second highest impact on the liveability of cities and, in conjunction with Biophilic housing, adds to the liveability of cities. Design strategies such as potted plants, flowerbeds, courtyard gardens, green walls and green roofs can be included in Biophilic activities and Biophilic housing.

The research results showed an urgent need for inclusion of sustainability education in universities providing courses in built-environment professions such as architecture, quantity surveying, construction management, and urban planning. In addition, the research results showed an urgent need to educate citizens in terms of "biophilic" activities and sustainability. Local government should allow citizens to participate in urban planning issues. Participation not only makes it possible to consider the needs and expectations of inhabitants, but it also encourages their sense of belonging.

The final regression equation showed that all the biophilic planning components tested had a positive 
impact on the liveability of Hashtgerd new town. The regression equation confirms that biophilic planning achieves liveability in Hashtgerd new town.

\section{CONCLUSION}

Biophilic planning is a new approach that focuses on healthy communities and healthy individual outcomes. It appears that biophilic design and planning led to achieving liveable cities. Liveable cities has long been a concept, but it has not yet been universally applied in practice. The data analysis from the research done in Hashtgerd new town in Iran show that it is possible to achieve liveable cities through biophilic planning. However, good governance structures and holistic urban planning are essential to achieve liveability. To gain a deep liveability improvement in a specific city, planners, engineers and all role players need to provide solutions to development based on all aspects of a liveable city, including components such as resilience, vitality, affiliation, identity, and accessibility. These factors necessitate more careful planning for future cities, revising old policies, and applying the successful experiences of newly established towns at regional, national, and international levels.

The main focus for the planners of new towns should include the concept of sustainability. Starting with location, incorporating the principles of sustainable development in the location finding stage of a new town has significant influence in the functionality of the towns and reduces the risk of their functional failure and unsustainability. Secondly, the social, environmental and economical aspects of sustainable urban environments require attention to issues beyond housing production. New approaches such as biophilic planning are needed to lead new cities to sustainability.

Other new towns should use these new approaches by focusing on their own local approach to liveability. New towns can use integrated thinking as a planning strategy of sustainable urban development. For a more attractive development of new towns such as Hashtgerd, the involvement of citizens in issues of urban development and planning processes is essential. Healthier, more socially connected individuals, families and communities will increase the likelihood of successful adaptation to this dynamic future, as integrated planning is the future for liveable cities.

\section{REFERENCES LIST}

AJZA SHOKOUHI, M., GHARAKHLUO, M. \& KHAZAEE NEJAD, F. 2012. Factors affecting the absorption of population to satellite new town. Human Geography Research Quarterly, No. 79, pp. 11-22.

APPLEYARD, D. 1981. Livable streets. Berkeley, CA: University of California Press.

BAHRAMI, H., SADATSAFAVI, M., POURSHAMS, A., KAMANGAR, F., NOURAEI, M., SEMNANI, S., BRENNAN, P., BOFFETTA, P. \& MALEKZADEH, R. 2006. Obesity and hypertension in an Iranian cohort study; Iranian women experience higher rates of obesity and hypertension than American women. BMC Public Health, 6(Article Number 158). https://doi. org/10.1186/1471-2458-6-15

BEATLEY, T. 2010. Biophilic cities, integrating nature into urban design and planning. Washington, DC: Island Press.

BEATLEY, T. \& MANNING, K. 1997. The ecology of place: Planning for environment, economy, and community. Washington, DC: Island Press.

BOONE, C.G. \& MODARRES, A. 2007. City and environment. Philadelphia, PN: Temple University Press.

BOONE, C.G., BUCKLEY, G.L., GROVE, J.M. \& SISTER, C. 2009. Parks and people: An environmental justice inquiry in Baltimore, Maryland. Annals of the Association of American Geographers, 99(4), pp. 767-782. https://doi. org/10.1080/00045600903102949

BOWLING, A. 1997. Research methods in health. Buckingham, UK: Open University Press.

BUCHWALD, E. (Ed.). 2003. Toward the livable city. Minneapolis, MN: Milkwood Editions.
BURNS, N. \& GROVE, S.K. 1997. The practice of nursing research conduct, critique, and utilization. Philadelphia, PN: W.B. Saunders and Co.

CALLICOTT, J.B. [n.d.]. Biophilia. [online]. Encyclopedia of Science, Technology, and Ethics. Available from: $<$ http://www.encyclopedia.com/science/ encyclopedias-almanacs-transcriptsand-maps/biophilia> [Accessed: 30 November 2016].

CAMPBELL, S. 1996. Green cities, growing cities, just cities? Journal of the American Planning Association, 62(3), pp. 296-312. https://doi. org/10.1080/01944369608975696

CASTELLATI, A. 1997. The nature of livability. In: Lennard, S.H., von Ungern-Sternberg, S. \& Lennard, H.L. (Eds). Making cities livable - Wegezurmenschlichen Stadt. International Making Cities Livable Conferences. Carmel, CA : Gondolier Press, pp. 19-33.

CENTRE FOR LIVEABLE CITIES (CLC). 2013. Better cities. [online]. Available from: <http://www.clc.gov.sg/> [Accessed: 14 April 2014].

CITIES PLUS. 2003. Cutting to the core principle of a sustainable urban system. Vancouver, Canada: The Sheltair Group Inc.

CROWHURST, S.H. \& LENNARD, H.L. 1987. Livable cities: People and places. Social and design principles for the future of the city. New York: Gondolier Press.

ECONOMIST INTELLIGENCE UNIT. 2013. A summary of the liveability ranking and overview. (online). Available from: <http://www.tfsa.ca/ storage/reports/Liveability_rankings_ Promotional_August_2013.pdf> [Accessed: 13 April 2014].

ELLIOTT, D.L. 2008. A better way to Zon: Ten principles to create more livable cities. Washington, DC: Island Press.

EVAS, P. (Ed.). 2002. Livable cities? Urban struggles for livelihood and sustainability. Oakland, CA: University of California Press Ltd.

FEDERAL MINISTRY OF EDUCATION AND RESEARCH (FMER). [n.d.]. Young cities - New towns (NT) in Iran. New towns as a concept for the sustainable development of mega region. Final report July 2005-March 2008. Berlin, Germany: Young Cities Project Centre. 
GRUCHOW, P. 1995. Grass roots: The universe of home (The world as home). Minneapolis, MN: Milkweed Editions.

HAHLWEG, D. 1997. The city as a family. In: Lennard, S.H., von Ungern-Sternberg, S. \& Lennard, H.L. (Eds). Making cities livable - WegezurmenschlichenStadt. International Making Cities Livable Conferences. Carmel, CA: Gondolier Press, pp. 13-19.

HEYNEN, N., PERKINS, H.A. \& ROY, P. 2006. The political ecology of uneven urban green space - The impact of political economy on race and ethnicity in producing environmental inequality in Milwaukee. Urban Affairs Review, 42(1), pp. 3-25. https://doi. org/10.1177/1078087406290729

HORNBY, A.S. \& TURNBULL, J. 2010. Oxford Advanced Learner Dictionary. $8^{\text {th }}$ edition. Oxford: Oxford University Press.

JACOBS, A. \& APPLEYARD, D. 1987. Toward an urban design manifesto. In: Le Gates, R. \& Stout, F. (Eds). 1996. The city reader. New York: Routledge, pp. 115-116.

KELLERT, S.R. 2005. Building for life: Understanding and designing the human-nature connection. Washington, DC: Island Press.

KELLERT, S.R. 2012. Birthright: People and nature in the modern world. New Haven, CT: Yale University Press.

LENNARD, H. 1997. Principles for the livable city. In: Lennard, S.H., von Ungern-Sternberg, S. \& Lennard, H.L. (Eds). Proceedings of the 17 th International Making Cities Livable Conferences, 5-9 September, 1995, Freiburg, Germany (Making cities livable - Wege zur menschlichen Stadt). Carmel, CA: Gondolier Press, pp. 15-17.

MAYRING, P. 2000. Qualitative content analysis [28 paragraphs]. Forum Qualitative Sozialforschung / Forum: Qualitative Social Research, 1(2), Art. 20, http://nbn-resolving.de/ urn:nbn:de:0114-fqs0002204

McPHERSON, G., SIMPSON, J.R., PEPER, P.J., MACO, S.E. \& XIAO, Q.F. 2005. Municipal forest benefits and costs in five US cities. Journal of Forestry, 103(8), pp. 411-416.

MERCER INSTITUTE. 2014. Quality of living reports and location evaluation reports. [online]. Available from: http:// www. imercer.com/products/2014/qualityof-living. aspx. [Accessed: 13 April 2014].
PAKZAD, J., HOSSEINZADEH LOTFI, F. \& JAHAN SHAH LOU, L. 2007. Assessment of new town selfsufficiency based on working and nonworking trips by mathematical models. International Journal of Contemporary Mathematical Sciences, 2(12), pp. 591-600. https://doi.org/10.12988/ ijcms.2007.07057

PATAKI, D.E., CARREIRO, M.M., CHERRIER, J., GRULKE, N.E., JENNINGS, V., PINCETL, S., POUYAT, R.V., WHITLOW, T.H. \& ZIPPERER, W.C. 2011. Coupled biogeochemical cycles in urban environments: Ecosystem services, green solutions and misconceptions. Special issue of Frontiers in Ecology and the Environment, 9(1), pp. 27-36.

PINCETL, S. 2010. From the sanitary city to the sustainable city: Challenges to institutionalizing biogenic (nature's services) infrastructure. Local Environment, 15(1), pp. 43-58. https:// doi.org/10.1080/13549830903406065

PINCETL, S., GILLESPIE, T., PATAKI, D.E., SAATCHI, S. \& SAPHORES, J.D. 2012. Urban tree planting programs, function or fashion? Los Angeles and urban tree planting campaigns. Geojournal, 78(3), pp.475-493. http:// dx.doi.org/10.1007/s10708-012-9446-x.

PLATT, R.H. 1994. The ecological city: Preserving and restoring urban biodiversity. Amherst, MA: University of Massachusetts Press.

THOMAS, D.R. 2006. A general inductive approach for qualitative data analysis. American Journal of Evaluation, 27(2), pp. 237-246. https:// doi.org/10.1177/1098214005283748

TIMMER, V. \& SEYMOAR, N-K. 2005. The livable city. Vancouver Working Group Discussion Paper for the The World Urban Forum. Vancouver, Canada: International Centre for Sustainable cities, pp. 1-58.

UYANIK, G.K. \& GÜLER, N. 2013. A study on multiple linear regression analysis. Procedia - Social and Behavioral Sciences, 106(2013), pp. 234-240. https://doi.org/10.1016/j. sbspro.2013.12.027

VITOUSEK, P., MOONEY, H.A., LUBCHENCO, J. \& MELLILO, J.M. 1997. Human domination of earth's systems. Science, New Series, 277(5325), pp. 494-499.

WIKIPEDIA. 2017. Hashtgerd. Available from: <https://en.wikipedia.org/wiki/ Hashtgerd> [Accessed: 22 Februrary 2017].
WILSON, E.O. 1993. Biophilia and the conservation ethic. In: Kellert, S. \& Wilson, E.O. (Eds). The biophilia hypothesis. Washington, DC: Shearwater Books, pp. 31-40.

WOLCH, J., WILSON, J.P. \& FEHRENBACH, J. 2005. Parks and park funding in Los Angeles: An equity mapping analysis. Geographical Review, 26(1), pp. 4-35. https://doi. org/10.2747/0272-3638.26.1.4

ZEBARDAST, E. \& JAHAN SHAH LOU, L. 2007. Investigating the performance of the Hashtgerd New Town in attracting population overflow. Geography and Development (Quarterly), 5(10), pp. 5-22.

ZIARI, K. \& GHARAKHANLOU, M. 2009. A study of Iranian new towns pre- and postrevolution. International Journal of Environmental Research, 3(1), pp. 143-154. 